
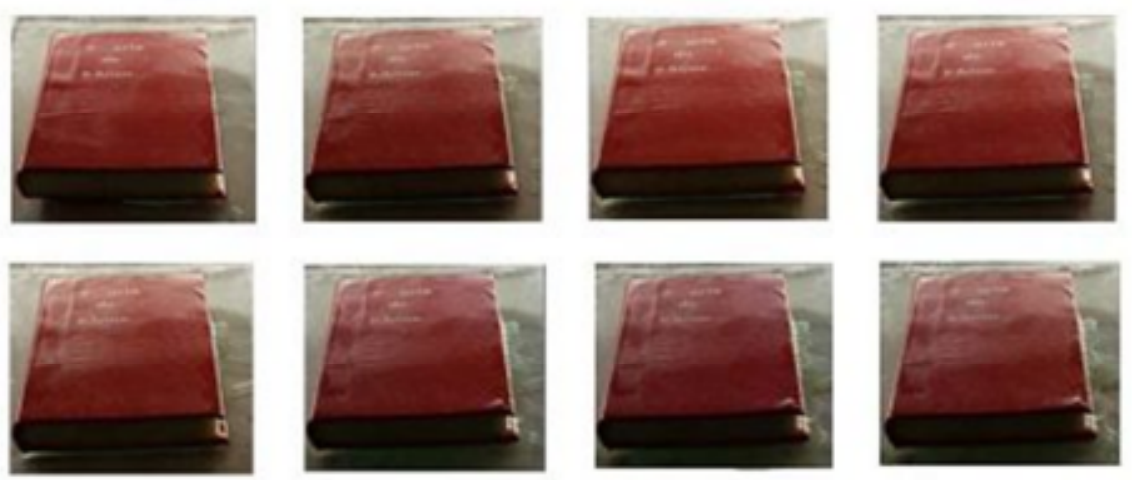

Ilustração Alexandre Resende Fotos Fabiana Fernandes

\title{
O sebo e a difusão da leitura
}

\section{Amadeu Coccó Rossi por Conceição Bicalho}

Amadeu Coccó Rossi é dono do mais famoso sebo de Belo Horizonte. Nascido no distrito de Passagem de Mariana, em 1916, ele perdeu o pai aos quatros anos e foi morar num orfanato, de onde só saiu em 1925. Seu primeiro emprego foi na mina da Companhia Mineira de Passagem. Em 1931, veio para Belo Horizonte. Sua primeira experiência como vendedor de livros foi em 1932, quando começou a trabalhar na Livraria Morais. Em 1948, comprou a biblioteca pessoal de Milton Pedrosa e tornouse alfarrabista.

A Livraria Amadeu completará 59 anos em fevereiro de 2007. Seu Amadeu, aos 89 anos, continua atrás do balcão, fazendo livros usados trocarem de mãos. Ele é o "banco de dados" da livraria, "acessado" a toda hora pelos funcionários: sabe onde está cada volume, até algum que já chegou há mais de uma semana.

Conceição Bicalho é Mestre em Artes Visuais pela Escola de Belas Artes/UFMG. Artista plástica, ilustradora e professora de Ilustração no Departamento de Desenho da EBA desde 2003. Foi professora de Xilogravura, Desenho e Cerâmica na UEMG no período de 1998 a 2002 .

\section{Conceição Bicalho - Por que "eles" não lêem?}

Amadeu Rossi - Ah, a vida agitada, a televisão, mal dá para ler o jornal... O pessoal chega em casa muito cansado... a vida é essa. 


\section{Mas foi sempre assim?}

Não. Na época em que eu montei minha loja, o pessoal lia. Até na pescaria o pessoal levava um livro pra ler. Às vezes não tinha peixe, mas tinha livro. Em 1948, as pessoas liam, ah... havia muito mais livrarias: Itatiaia, Oliveira \& Costa, Rex, Oscar Nicolai, Tapir, Livraria América. Houve umas dez que fecharam no período da crise. Mas naquele tempo, as pessoas idosas liam demais: liam para os netos e para os filhos. Aquelas casas grandes tinham bibliotecas enormes! Depois veio a especulação imobiliária, o pessoal se desfez das bibliotecas, houve a debandada geral.

\section{Quando isso aconteceu?}

Por volta de 1948, quando todos compravam livros. De 1970/80 para cá, as coisas pioraram, nunca houve uma crise como essa. Estamos lutando para vender, para manter os fregueses.

\section{Mas por que a maioria das pessoas não lêem? Na sua opinião, quais são os não-leitores, ontem e hoje?}

São pessoas que nem entram em livrarias, que nunca querem saber de livros. Eu já vi pessoas dizendo: "Nunca li um livro". Não-leitor é isso: "Nunca li um livro". Não têm nada pra ler! Há pessoas que têm birra de livros e outras que viram a noite lendo. Mas a livraria, apesar de toda essa crise que está aí, não pode parar. Já tivemos mais lojas, mas por encargos sociais, empregados etc., fomos obrigados a fechar. Manter uma loja dessas não é brincadeira, são tantos impostos que você nem queira calcular!

\section{Além dos motivos que o senhor colocou, existe algum outro que impede que as pessoas se tornem leitoras?}

Tem pessoas que têm birra de livros e tem pessoas que se importam de ler. Tem pessoas que viram a noite lendo, lendo. Mas a livraria, graças a Deus, apesar de toda essa crise, "nós estamos aí", não podemos parar.

Nós já tivemos mais lojas, mas por encargos sociais, empregados e tudo isso, fomos obrigados a fechar. Manter uma loja dessas não é brinquedo, são tantos impostos que você nem queira calcular! Você nem imagina, os encargos sociais: INSS, tudo, o valor - nós pagamos almoço, condução, comissão e ordenado - são quatro itens para poder incentivar. 
Além dos motivos que o senhor colocou, existe algum outro que impede que as pessoas se tornem leitoras?

É justamente essa vida muito agitada, o barulho... O pessoal chega em casa preocupado: pagar isso, pagar aquilo, estudo dos meninos... O livro didático, por exemplo, está sendo doado pelo governo. De primeiro, o pessoal comprava livros da la à 4 a série, depois os livros da Admissão e de $5 a$ à $8 a$ série. Quando se passava de uma série para outra, os livros eram trocados, nós dávamos descontos e o livro usado facilitava o estudo dos alunos. Agora o Governo está doando, acabou nosso comércio!

A seu ver, as novas edições, de um modo geral, são caras?

Além de caras, as vendas de novas edições com valores fracionários (como R\$ 49,90) iludem o comprador.

Por que o senhor optou por esse tipo de comércio, que permite compra e venda de livros mais baratos?

Justamente porque permite a compra e a venda mais baratas. Outro dia chegou um freguês aqui para comprar um livro de $\mathrm{R} \$$ 35,00 e o levou por $\mathrm{R} \$ 10,00$ !

o senhor dizia que o tempo limita a leitura de todos. Então, ler é um privilégio? Uma conquista? ou um capricho?

Ler? É uma conquista! Eu, por exemplo, sabe a que horas leio? De 2 às 4 da madrugada. Se não ler, não durmo. Preciso ler! É a melhor coisa que tem, a gente nem vê mosquito voar. Sabe por quê? O silêncio é maior e faz a gente absorver mais a leitura.

\section{Que tipo de livro o senhor lê?}

Viagens, memórias, leio de tudo. Minha sócia também gosta de ler: como espírita, ela acha que tudo tem a ver, incluindo-se aí os novos escritores.

\section{Qual é a faixa etária que mais procura por livros hoje?}

São as pessoas com 25/30 anos. A rapaziada de hoje não quer saber de leitura. Quando muito, só a dos estudos obrigatórios. Mas também a oferta de leitura para os jovens é muito dirigida 
para livros didáticos, esporte etc. Na faixa dos 30, é que o leitor se torna mais compenetrado, mais quieto.

\section{No sebo, é muito grande a procura de livros didáticos?}

Sim, venham ver! Está tudo aqui. (Aponta-nos as prateleiras cheias e bem organizadas: livros de Línguas, Matemática, Física, Biologia, Química, História, Geografia).

\section{O senhor acha vantagem trabalhar com livros didáticos?}

Não. A partir do próximo ano, já não trabalharei mais. O governo está doando, não é? O livro do governo é reutilizável, depois que a pessoa lê, estuda, tem que devolver. Ele não pode ser vendido. Isso se tornou uma dificuldade para nós.

\section{Mas há outro tipo de leitor, que garanta seu comércio?}

Sim, nas áreas de Filosofia, História, Geografia, Biografias, Literatura, Literatura Infanto-juvenil e muitas outras.

\section{O senhor percebe imediatamente o perfil de um grande leitor?}

Percebo. Pela fisionomia. Outro dia um rapaz me disse: "Amadeu, o senhor está sempre no meio dos livros, o senhor tem uma fisionomia de literato!" (risos). Eu fiquei tão satisfeito! Sabe por quê? É que a gente está sempre lidando com os livros e, de fato, é como se a gente incorporasse seus conteúdos. Parece que o livro nos fotografa. A gente também fotografa o livro.

- senhor conheceu não-leitores que, na batalha diária, adquiriram um conhecimento que equivale ao de seus melhores leitores?

Um dia, um freguês me deixou admirado. "Amadeu", ele disse, "estive aqui, você me deu um livro de presente... tomei gosto pela leitura... Seu livro me fez ler, comprar outros, ver novas realidades." Isso é que faz as coisas ficarem bonitas! Quando aparece alguém que sinto não ser muito chegado à leitura, dou-lhe um livro de presente. Há certo tempo, aqui veio um rapazinho com o avô. Dei-lhe um livro. Até hoje ele aparece - já está um rapagão - e me diz: "Aquele livro que você me deu está guardado com todo o carinho lá em casa". 


\section{É curioso observar o poder que o livro exerce quando dado de presente!}

É verdade. Eu recebi um representante da Associação dos Comerciários que me pediu uma doação. Eu já separei umas dez coleções que vou enviar a eles. Faço sempre doações desse tipo, e também faço abatimento nos preços. Se alguém diz que

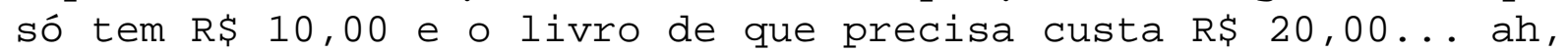
rapaz... pode levar! Leitor é igual a passarinho, mais vale um na mão que dez voando!

\section{Como admirador do objeto-livro, quais dos que já passaram por suas mãos considera mais importantes? Os livros raros?}

Por minhas mãos, já passaram muitos livros dos séculos XVII, XVIII e XIX. Um dos mais importantes foi o Formulário Chernovitz, que era de mil oitocentos e noventa e poucos. Esse foi um livro muito famoso! Quando os alunos das Escolas de Farmácia e de Minas de Ouro Preto formavam, eles pegavam um formulário desses e montavam uma Farmácia (pena que eu não tenha aqui um exemplar para lhe mostrar). Era o formulário das farmácias famosas, antigas. Era então bem considerado, uma verdadeira academia (a farmácia era uma verdadeira academia). Ele servia a juiz de Direito, advogado, chefe de Estação - que naquela época era muito cotado - fazendeiros, gente da elite. o formulário era um lugar onde se resolviam todos os problemas. Até o prefeito o consultava. O formulário respondia a tudo, a todas as perguntas sobre doenças, até sobre a gripe espanhola. Uma vez, aconteceu-me um caso curioso! Eu tinha adquirido um certo livro em nem sei quantos mil exemplares. Um rapaz de São Paulo me procurou e disse: "Seu Amadeu, eu estou precisando voltar pra São Paulo, estou aqui sozinho, não tenho nem um tostão. O senhor podia me dar uns livros pra eu vender?" Eu peguei uns vinte exemplares, carimbei "Livraria Amadeu Editora" e ele saiu pela rua Rio de Janeiro. Entrava em todos os lugares, até em botequim, e vendia. Voltava e pegava mais e vendia... Isso foi na década de 50, quando o pessoal tinha fome de leitura.

\section{Seu Amadeu, o que ocorreu com suas lojas após a Internet?}

Caíram muito as vendas. Mas meu filho e meu neto já estão na Internet e acreditam que devemos entrar na rede, porque é uma maneira de recebermos pedidos do mundo inteiro. o pessoal vai ter acesso aos títulos que temos em sua própria casa e isso vai facilitar a vida de todo mundo! 
Quais são os motivos daqueles que o procuram para vender um livro, uma coleção ou uma biblioteca inteira?

Existem dois tipos de vendedores: os que vendem por necessidade e os que vendem para desocupar espaço. Já me aconteceu um caso curioso, há muito tempo. Chegou um freguês no sebo para vender um dicionário Caldas Aulet, dois volumes. Naquela época, o pessoal procurava esse dicionário, e também o Morais que era muito famoso. A moeda era diferente da de hoje. Ficamos ali discutindo o preço. O livro estava encapado. O freguês dizia: "Estou precisando do dinheiro para viajar, me dê uns 500 réis." E eu, firme: "Não posso!" O freguês insistindo: "Mas estou precisando." E eu: "Não posso". Durante a discussão, ele acabou tirando a capa do livro. E descobriu, entre a capa e o livro, uma nota de 500 réis! (risos, admiração). Isso ficou na história. O freguês dizia, contente: "Ô Amadeu, olha só o que eu descobri, graças à sua insistência."

Considerando seus 65 anos de convivência com os livros, o senhor pensa que a qualidade de impressão de um livro tem efeitos na formação do leitor? Há diferenças de qualidade que alteram a condição de leitura?

Há pessoas que procuram livros por sua raridade. Vejam esses aqui. (Mostra a estante dos livros mais antigos da loja, dentre os quais encontram-se os Códigos de Direito Canônico). Existem fregueses que procuram livros por necessidade técnica, há livros para orquidófilos, por exemplo. A impressão dos livros melhorou $100 \%$. Hoje isso faz muita diferença para o leitor. A impressão e as máquinas são muito mais velozes e eficientes, antes era uma dificuldade para se fazer livros.

o senhor disse que antes o pessoal lia mais. Com o aumento da população e da qualidade dos impressos, como pôde haver uma queda no número de leitores?

Existe uma média de compradores que se mantém. Se eu abrir minha loja diariamente, mantenho sempre esse número.

Isto quer dizer que sempre haverá uma quantidade previsível de leitores?

Sim, mas calcada na diversidade da oferta de leituras: Psicologia, Filosofia, Direito, Engenharia, Economia, Administração, Contabilidade, Livros técnicos, Dicionários, Literatura etc. Um amigo de São Paulo que só vendia livros de 
Txt: Leituras Transdisciplinares de Telas e Textos, Belo Horizonte, v.2, n.4, p.85-91, 2006

Direito teve que, na atualidade, diversificar sua oferta. Tenho fregueses antigos: bisavô, avô, pai, neto, quatro gerações, a família inteira. Quando alguém faz uma reportagem comigo, no dia seguinte aumentam as vendas. Haverá um lançamento, no Palácio das Artes, de uma biografia minha onde eu falo de tudo isso. Aguardem para ler. 